\title{
Role of Mycobacterium avium catalase-peroxidase (KatG) in the pathogenesis of MAC disease in HIV patients
}

\author{
Romica Latawa', Ajay Wanchu², Indu Verma ${ }^{1 *}$ \\ From First International Science Symposium on HIV and Infectious Diseases (HIV SCIENCE 2012) \\ Chennai, India. 20-22 January 2012
}

\section{Background}

The mycobacterial catalase-peroxidases protect it from the reactive oxidative metabolites and allow its survival within the host phagocytes. We compared the virulence of Mycobacterium avium complex (MAC) clinical isolates with varying catalase activity recovered from the blood of HIV patients in terms of invasiveness and intracellular multiplicity in host cells. The catalase activity in MAC isolates was also analysed in context to CD4 counts and clinical presentation of mycobacterial disease in HIV patients.

\section{Methods}

Catalase activity of KatG protein of 51 mycobacterial isolates from HIV patients was determined. MAC isolate with maximum catalase activity (KatG-max) was compared to isolate having minimum activity (KatG-min) for adherence, intracellular replication and katG mRNA expression by ZN staining, colony forming units (CFU) enumeration and RT-PCR respectively in A549 and HT29 cell lines.

\section{Results}

Catalase activity of mycobacterial isolates was found to be inversely related to $\mathrm{CD} 4$ counts and unrelated to the clinical presentation of mycobacterial disease in HIV patients. The intracellular replication of KatG-max isolate was found to be 2 fold higher than KatG-min at $3^{\text {rd }}$ day of infection (doi) [ $<<0.001]$, whereas, it was comparable at $1^{\text {st }}$ doi. CFU enumeration results correlated well with the levels of katGm RNA expression.

\footnotetext{
* Correspondence: induvermabio@gmail.com

'Department of Biochemistry, Postgraduate Institute of Medical Education and Research, Chandigarh, India

Full list of author information is available at the end of the article
}

\section{Conclusion}

The MAC isolates having maximum catalase activity and increased katGm RNA expression was favoured for its survival and replication in the host cells. High levels of catalase activity in isolates from HIV patients with low CD4 counts suggest an important role of KatG in the establishment and progression of disseminated MAC disease.

\section{Author details}

'Department of Biochemistry, Postgraduate Institute of Medical Education and Research, Chandigarh, India. '2Department of Internal Medicine, Postgraduate Institute of Medical Education and Research, Chandigarh, India.

Published: 4 May 2012

\section{doi:10.1186/1471-2334-12-S1-P15}

Cite this article as: Latawa et al:: Role of Mycobacterium avium catalaseperoxidase (KatG) in the pathogenesis of MAC disease in HIV patients. BMC Infectious Diseases 2012 12(Suppl 1):P15.

\section{Submit your next manuscript to BioMed Central and take full advantage of: \\ - Convenient online submission \\ - Thorough peer review \\ - No space constraints or color figure charges \\ - Immediate publication on acceptance \\ - Inclusion in PubMed, CAS, Scopus and Google Scholar \\ - Research which is freely available for redistribution

